\title{
EVALUATION OF ANTICANCER ACTIVITY OF ETHANOLIC EXTRACT OF CYPERUS KYLLINGIA ENDL. IN EHRLICH ASCITES CARCINOMA-INDUCED SWISS ALBINO MICE
}

\section{AMITES GANGOPADHYAY ${ }^{*}$, MAINAK CHAKRABORTY² ${ }^{2}$, PALLAB KANTI HALDAR ${ }^{3}$, NITAI CHAND CHAULYA ${ }^{1}$, AMITAVA GHOSH ${ }^{4}$}

${ }^{1}$ Department of Pharmaceutical Chemistry, Gupta College of Technological Sciences, Asansol, West Bengal, India. ${ }^{2}$ Department of Pharmacology, Himalayan Pharmacy Institute, Majhitar, Rangpo, East Sikkim, India. ${ }^{3}$ Department of Pharmaceutical Technology, Jadavpur University, Kolkata, West Bengal, India. ${ }^{4}$ Department of Pharmaceutics, Bengal College of Pharmaceutical Sciences and Research, Bidhannagar, DurgapurWest Bengal, India. Email: amites9@rediffmail.com

Received :12 June 2018,Revised and Accepted: 13 August 2018

ABSTRACT

Objective: The purpose of the study was to evaluate the antitumor and antioxidant status of ethanolic extract of Cyperus kyllingia Endl. on Ehrlich ascites carcinoma (EAC)-treated mice.

Methods: The determination of in vivo antitumor activity was performed using EAC cells inoculated mice groups ( $\mathrm{n}=12$ ). The groups were treated for 9 consecutive days with ethanolic extract of $C$. kyllingia (EECK) at the doses of 20 and $40 \mathrm{mg} / \mathrm{kg}$ b.w., respectively. After $24 \mathrm{~h}$ of the last dose, half of the mice were sacrificed and the rest were kept alive for assessment of increase in life span. The antitumor potential of EECK was assessed by evaluating tumor volume, viable and non-viable tumor cell count, tumor weight, hematological parameters, and biochemical estimations. Furthermore, antioxidant parameters were assayed by estimating liver tissue enzymes.

Results: EECK showed direct cytotoxicity on EAC cell line in a dose-dependent manner. EECK exhibited significant $(\mathrm{p}<0.05)$ decrease in the tumor volume, viable cell count, tumor weight, and elevated the life span of EAC tumor-bearing mice. The hematological profile, biochemical estimations, and tissue antioxidant assay were reverted to normal level in EECK-treated mice.

Conclusion: Experimental results revealed that EECK possesses potent antitumor and antioxidant properties. Further, research is going on to find out the active principle(s) of EECK for better understanding of mechanism of its antitumor and antioxidant activity.

Keywords: Cyperus kyllingia Endl, Ehrlich ascites carcinoma, Antioxidant, Antitumor, Superoxide dismutase, glutathione.

(C) 2018 The Authors. Published by Innovare Academic Sciences Pvt Ltd. This is an open access article under the CC BY license (http://creativecommons. org/licenses/by/4. 0/) DOI: http://dx.doi.org/10.22159/ajpcr.2018.v11i10.27926

\section{INTRODUCTION}

Cancer is one of the most life-threatening diseases in which a group of abnormal cells grows uncontrollably by disregarding the normal rules of cell division. Cancer is characterized by uncontrolled growth, invasion (intrusion on and destruction of adjacent tissues), and metastasis (spread to other locations in the body through lymph or blood). It is one of the leading causes of the death worldwide. It is estimated that $12.5 \%$ of the population dies due to cancer [1]. Nowadays, chemotherapy is the most effective treatment for cancer, but existing chemotherapeutic agents adversely affect our host cell also, especially bone marrow, epithelial tissues, gonads, and the reticulaendothelial system [2]. Natural products have been the mainstay in cancer chemotherapy for the past 30 years. Over $60 \%$ of the clinically used anticancer drugs are of natural origin and most of them are derived from plants [3]. Phytochemicals have minimal toxicity on host cell compare to chemotherapeutic agent. Therefore, researches are still going on medicinal plants in search of new effective anti-carcinogenic agent which can reverse progression of cancer.

Cyperus kyllingia Endl. (Cyperaceae) is a perennial herb with creeping underground stem commonly found in tropical regions of the world. According to ethnomedical investigation, this plant was found to have numerous biological activities such as antidiarrheal, diuretic, stomachic, anthelmintic, and expectorant activities, and it is also used in fever, hepatopathy, splenopathy, diabetes, and tumors [4]. Previously, phytochemical analysis was performed and terpenes such as $\alpha$-cyperone, $\beta$-selinene, and $\alpha$-humulene were found in underground part of this plant [5]. The present study was carried out to evaluate the anticancer effect of root extract of $C$. kyllingia Endl. against Ehrlich's ascites carcinoma (EAC) in Swiss albino mice. There is no scientific report available on biological effect of root extract from $C$. kyllingia Endl. Therefore, this effort has been made to investigate the antiproliferative effect of $C$. kyllingia Endl.

\section{METHODS}

\section{Chemicals}

5-fluorouracil from Sigma (St. Louis, MO); trichloroacetic acid from Merck (Mumbai, India); thiobarbituric acid, nitroblue tetrazolium chloride from Loba Chemie (Mumbai, India); 5,5'-dithiobis-2nitrobenzoic acid, phenazonium methosulfate, nicotinamide adenine dinucleotide, and reduced glutathione (GSH) from SISCO (Mumbai, India). All the other reagents used were of analytical reagent grade obtained commercially.

\section{Plant collection and extraction}

The plant was collected from the Sonamukhi forest range of Ichharia village, Bankura, West Bengal, India. Moreover, the specimen was authenticated by B.S.I.(CNH/71/2011/Tech.II/), Shibpur, Howrah, West Bengal, India. In brief, the roots were carefully washed under running tap water followed by sterile distilled water and dried at room temperature for 5 days. Then, roots were pulverized to a fine powder and stored in air-tight bottles. The root powder was extracted with ethanolic by Soxhlet extraction apparatus. The extract was then kept in distillation for solvent evaporation and remaining solvent was completely removed 
under reduced pressure in a rotary vacuum evaporator (Buchi R-210). The concentrated extract was stored in vacuum desiccators.

\section{Animals}

Male Swiss albino mice, an average body weight 20-22 g, were taken for this experiment. The mice were obtained from the animal house, B. N. Ghosh and Co. Kolkata, India, and were grouped and housed in polyacrylic cages $(38 \mathrm{~cm} \times 23 \mathrm{~cm} \times 10 \mathrm{~cm})$ with not more than six animals per cage. Animals were maintained under standard laboratory conditions (temperature $25 \pm 2{ }^{\circ} \mathrm{C}$ and dark/light cycle $14 / 10 \mathrm{~h}$ ). They were allowed free access to standard dry pellet diet (Hindustan Lever, Kolkata, India) and water ad libitum. The mice were acclimatized to laboratory conditions for 7 days before commencement of the experiment. All procedures described were reviewed and approved by the University Animal Ethical Committee.

\section{Transplantation of tumor cell}

EAC cells were obtained from Chittaranjan National Cancer Institute, Kolkata, India. The EAC cells were maintained in vivo in Swiss albino mice by intraperitoneal transplantation of $2 \times 10^{6}$ cells per mouse after every 10 days. Ascetic fluid was drawn out from EAC cell-bearing mouse at the log phase (days 7-8 of tumor bearing) of the tumor cells. Each animal injected intraperitonially with $0.1 \mathrm{ml}$ of tumor cell suspension containing $2 \times 10^{6}$ tumor cell [6].

\section{Determination of acute toxicity}

As per OECD guideline 425, the acute oral toxicity of EECK in Swiss albino mice was performed as per previously described method Gangopadhyay et al., 2017 [7,8].

\section{Treatment schedule}

A total of 60 Swiss albino mice were divided into five groups $(\mathrm{n}=12)$ and given food and water ad libitum. All the animals in each group, except Group-I (normal control), received EAC cells $\left(2 \times 10^{6}\right.$ cells/mouse i. p.). This was taken as day "0." Group-I served as normal saline $(5 \mathrm{ml} / \mathrm{kg}$ i. p.) and Group-II served as EAC control. $24 \mathrm{~h}$ after EAC transplantation, Group-III and IV received ethanolic extract of $C$. kyllingia (EECK) root at a dose of 20 and $40 \mathrm{mg} / \mathrm{kg}$ i. p. for 9 consecutive days, respectively. Group-V received reference drug 5-FU (20 mg/kg i. p.) for 9 consecutive days [9]. $24 \mathrm{~h}$ of last dose, six animals of each group were sacrificed by cervical dislocation to measure antitumor, hematological, and biochemical parameters (livers) and rest of the animals were kept with food and water ad libitum to check percentage increase life span of the tumor host. The anticancer activity of EECK was measured in EAC animals with respect to the following parameters.

\section{Determination of biochemical parameters}

Serum biochemical parameter such as total proteins, serum glutamate oxaloacetate transaminase (SGOT), serum glutamate pyruvate transaminase (SGPT), serum alkaline phosphatase (SALP), and serum bilirubin was done using commercially available kits manufactured by the Span Diagnostics Ltd., Surat, India.

Determination of tumor volume, packed cell volume, and tumor weight

The mice were dissected and the ascites fluid was collected from the peritoneal cavity. Tumor volume, packed cell volume, and tumor weight were measured according to the previously described standard methods in our laboratory [10].

\section{Determination of viable and non-viable tumor cell count}

The ascites fluid was taken in a white blood cell (WBC) pipette and diluted 100 times. Then, a drop of the diluted suspension was paled on the Neubauer counting chamber, and the cells were then stained with Trypan blue $(0.4 \%$ in normal saline) dye. The cells that did not take up the dye were viable and those took the stain were non-viable. These viable and non-viable cells were counted [11].

Cellcount $=\frac{(\text { number of cells } \times \text { dilutionfactor })}{(\text { area } \times \text { thickness of liquidflim) }}$
Determination of percentage increase life span (\% ILS)

The effect of EECK on percentage increased in life span was calculated on the basis of the mortality rates of the experimental mice [10].

ILS $\%=\left(\frac{\text { Mean survival time of treated group }}{\text { Mean survival time of untreated group }}-1\right) \times 100$

Mean survival time $=\frac{\text { First death }+ \text { last death }}{2}$

\section{Determination of hematological parameters}

At the end of the experimental period, the next day after an overnight fasting blood was collected from freely flowing tail vein and used for estimation of hemoglobin ( $\mathrm{Hb}$ ) content, red blood cell (RBC) count, WBC count, and lymphocyte count by standard procedures [2]

\section{Determination of tissue antioxidant parameters}

Blood was collected from mice by cardiac puncture and was kept for $15 \mathrm{~min}$ for clotting and then centrifuged at $5000 \mathrm{rpm}$ for $10 \mathrm{~min}$. The supernatants (serum) were collected and total protein, bilirubin, ALT, ASt, and ALP were determined using the diagnostic reagent kit (Span Diagnostics Ltd., Surat, India), using the autoanalyzer instrument (SELECTRA PRO XS, Merck Limited, Germany).

\section{Statistical analysis}

Statistical analysis was performed using GraphPad Prism (version 5.0, GraphPad Software Inc., San Diego, CA) software. The experimental results were expressed as mean \pm standard error of mean. Statistical significance was analyzed by one-way ANOVA followed by Dunnett's post hoc test of significance. $p<0.05$ was considered as statistically significant.

\section{RESULTS AND DISCUSSION}

\section{Determination of acute toxicity}

The $\mathrm{LD}_{50}$ of the C. kyllingia ethanolic root extract was found to be $251.3014 \mathrm{mg} / \mathrm{kg}$ body weight for i.p. According to OECD guidelines, it is considered as $\mathrm{LLD}_{50}$ cutoff value. Dose selected for pharmacological studies by fixed dose methods is mentioned below. Ethanolic extracts of C. kyllingia roots used for anticancer study were 20 and $40 \mathrm{mg} / \mathrm{kg}$ body weight which were much lower than the $\mathrm{LD}_{50}$.

\section{Determination of direct tumor-related parameters}

Antitumor activity of EECK against EAC tumor-bearing mice was assessed by the parameters such as tumor volume, packed cell volume, cell count (viable and non-viable), mean survival time, and percentage increase of life span. The results are shown in Table 1. Tumor volume and packed cell volume were significantly decreased in EECK-treated group in compare with normal control group. Viable cell count was significantly low in EECK-treated group at the dose of $20 \mathrm{mg} / \mathrm{kg}$ and $40 \mathrm{mg} / \mathrm{kg}$ and non-viable cell count was comparatively increased in EECK-treated group than the EAC control group. Furthermore, mean survival time and percentage increase of life span were increased on EECK-treated group in a dose-dependent manner. From these results, it can be concluded that EECK extract has antitumor activity on EACinduced mice in a dose-dependent manner.

\section{Hematological parameters}

RBC level was decreased in EAC control group and WBC level was increased in EAC control group as compare with normal group according to Table 2. It was seen that RBC and Hb content was increased and WBC count was significantly reduced in EECK-treated group as compared with EAC control group.

\section{Biochemical parameters}

Biochemical parameters such as TP, SGOT, SGPT, and SALP levels were discussed in Table 3. SGOT, SGPT, and SALP levels are lower in normal group compare to EAC control group and TP level is higher in normal group than EAC control group. It was estimated that SGOT 
Table 1: Determination of direct tumor-related parameters

\begin{tabular}{|c|c|c|c|c|c|c|}
\hline \multirow[t]{2}{*}{ Groups } & \multirow[t]{2}{*}{ Tumor Volume (ml) } & \multirow[t]{2}{*}{ Packed cell volume (ml) } & \multicolumn{2}{|c|}{ Cell count $\left(\times 10^{7} / \mathrm{ml}\right)$} & \multirow[t]{2}{*}{ MST (day) } & \multirow[t]{2}{*}{ ILS\% } \\
\hline & & & Viable & Non-viable & & \\
\hline EAC control & $2.40 \pm 0.05$ & $2.02 \pm 0.03$ & $7.70 \pm 0.22$ & $0.66 \pm 0.06$ & 19 & 00 \\
\hline $\mathrm{EAC}+20 \mathrm{mg} / \mathrm{kg}$ & $1.98 \pm 0.04^{*}$ & $1.62 \pm 0.02 *$ & $6.40 \pm 0.22 *$ & $3.94 \pm 0.09 *$ & 23 & 21.05 \\
\hline $\mathrm{EAC}+40 \mathrm{mg} / \mathrm{kg}$ & $1.78 \pm 0.04^{*}$ & $1.40 \pm 0.03 *$ & $5.33 \pm 0.23^{*}$ & $4.46 \pm 0.23^{*}$ & 26 & 36.84 \\
\hline $\mathrm{EAC}+5-\mathrm{FU}(20 \mathrm{mg} / \mathrm{kg})$ & $0.70 \pm 0.04 *$ & $0.28 \pm 0.03^{*}$ & $2.71 \pm 0.15^{*}$ & $5.33 \pm 0.23 *$ & 38 & 100 \\
\hline
\end{tabular}

Shows the effect of EECK on various parameters such as tumor volume, packed cell volume, percentage of viable and non-viable cells, mean survival time, and the increase in life span. Values are represented as mean \pm SEM. ${ }^{*} \mathrm{p}<0.05$ when EAC control compared with treated groups. EECK: Ethanolic extract of Cyperus kyllingia, EAC: Ehrlich ascites carcinoma, SEM: Standard error of the mean

Table 2: Hematological parameters

\begin{tabular}{|c|c|c|c|c|c|}
\hline Parameters & Normal & $\begin{array}{l}\text { EAC } \\
\text { control }\end{array}$ & $20 \mathrm{mg} / \mathrm{kg}$ EECK & $40 \mathrm{mg} / \mathrm{kg}$ EECK & $20 \mathrm{mg} / \mathrm{kg} 5-\mathrm{FU}$ \\
\hline $\mathrm{RBC}\left(\right.$ cell $\left.\times 10^{6} / \mathrm{mm}^{3}\right)$ & $5.48 \pm 0.10$ & $2.45 \pm 0.17^{* a}$ & $3.15 \pm 0.14$ & $4.15 \pm 0.17^{\# \mathrm{~b}}$ & $5.35 \pm 0.25^{\# \mathrm{~b}}$ \\
\hline WBC $\left(\right.$ cell $\left.\times 10^{6} / \mathrm{mm}^{3}\right)$ & $4.43 \pm 0.23$ & $7.5 \pm 0.28^{* a}$ & $6.4 \pm 0.23$ & $5.33 \pm 0.24^{\# b}$ & $5.09 \pm 0.10^{\# \mathrm{~b}}$ \\
\hline $\mathrm{Hb}(\mathrm{g} / \mathrm{dl})$ & $11.79 \pm 0.23$ & $4.47 \pm 0.29$ *a & $5.44 \pm 0.28^{\# \mathrm{~b}}$ & $6.73 \pm 0.27^{\# b}$ & $8.44 \pm 0.29^{\# \mathrm{~b}}$ \\
\hline
\end{tabular}

Effect of different concentration of the extracts on hematological parameters. Values are represented as mean \pm SEM. ${ }^{* a} \mathrm{p}<0.05$ when EAC control compared to normal, ${ }^{\# \mathrm{~b}} \mathrm{p}<0.05$, EAC control compared with treated groups. EECK: Ethanolic extract of Cyperus kyllingia, EAC: Ehrlich ascites carcinoma, SEM: Standard error of the mean

Table 3: Biochemical parameters

\begin{tabular}{|c|c|c|c|c|c|}
\hline Parameters & Normal & EAC control & $20 \mathrm{mg} / \mathrm{kg}$ & $40 \mathrm{mg} / \mathrm{kg}$ & $20 \mathrm{mg} / \mathrm{kg} \mathrm{5-FU}$ \\
\hline TP (g/dl) & $8.61 \pm 0.31$ & $4.25 \pm 0.24$ & $5.02 \pm 0.03$ & $6.7 \pm 0.37$ & $8.38 \pm 0.28$ \\
\hline SGOT (IU/L) & $77.33 \pm 1.45$ & $164.3 \pm 5.60^{\#}$ & $156.7 \pm 4.41^{*}$ & $98.33 \pm 4.41^{*}$ & $85.67 \pm 2.96^{*}$ \\
\hline SGPT (IU/L) & $38.00 \pm 4.93$ & $95 \pm 8.66^{\#}$ & $86.67 \pm 8.81^{*}$ & $71.67 \pm 6^{*}$ & $45 \pm 7.63^{*}$ \\
\hline SALP (KA/U) & $73.33 \pm 6.09$ & $155 \pm 12.58^{\#}$ & $131.7 \pm 6.09$ & $110 \pm 5.77^{*}$ & $81.67 \pm 17.40^{*}$ \\
\hline
\end{tabular}

Effects of different concentrations of the extract on serum parameters. Values are represented as mean \pm SEM. ${ }^{*} p<0.05$ when EAC control compared to normal, ${ }^{*} p<0.05$ when EAC control compared with treated groups. SGOT: Serum glutamate oxaloacetate transaminase, SGPT: Serum glutamate pyruvate transaminase, SALP: Serum alkaline phosphatase, EAC: Ehrlich ascites carcinoma, SEM: Standard error of the mean

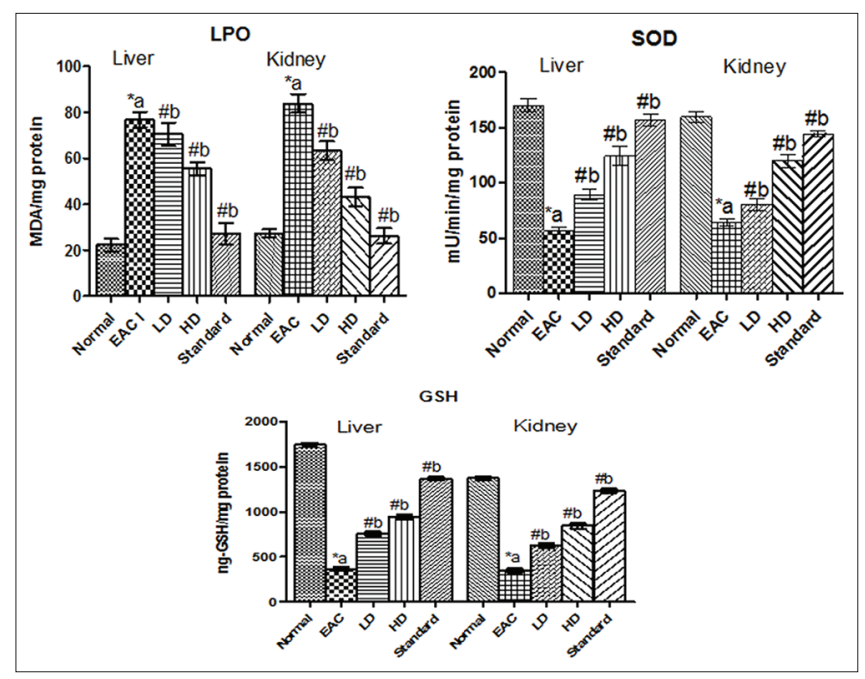

Fig. 1: Tissue antioxidant parameter. Effects of different concentrations of ethanolic extract of Cyperus kyllingia on lipid peroxide, superoxide dismutase, and glutathione. The values are represented as mean \pm standard error of the mean. ${ }^{a *} \mathbf{p}<0.05$ when Ehrlich ascites carcinoma (EAC) control compared to normal liver and kidney, ${ }^{\mathrm{b}} \mathrm{p}<0.05$ when treated groups compared to EAC liver and EAC kidney

and SGPT levels were significantly decreased in EECK-treated group $(20 \mathrm{mg} / \mathrm{kg}$ and $40 \mathrm{mg} / \mathrm{kg})$ in a dose-dependent manner. SALP level was decreased in EECK-treated group compare to EAC control group, and it was significant in $40 \mathrm{mg} / \mathrm{kg}$. TP level was increased in EECKtreated group in a dose-dependent manner as compared with EAC control group.

\section{DISCUSSION}

The present investigation was carried out to evaluate the antiproliferative property of ethanolic extract of indigenous plant of West Bengal region, i.e., C. kyllingia Endl. in EAC tumor-bearing mice. The EECK-treated animals at the doses 20 and $40 \mathrm{mg} / \mathrm{kg}$ significantly inhibited the tumor volume, packed cell volume, viable tumor cell count, and back the hematological parameters toward normal levels. In EAC tumor-bearing mice, rapid increase in ascites tumor volume was observed. Nutritional source for tumor cells is ascites fluid, and a rapid increase in ascites fluid with tumor growth would be a means to meet the nutritional requirement of tumor cells [3]. Treatment with EECK decreased the tumor volume, viable tumor cell count, and increased the life span of the tumor-bearing mice. The main criteria for any anticancer drug are the prolongation of the life span of animal [10]. In the present study, EECK increases the life span of EAC-bearing mice.

Usually, in cancer chemotherapy, the major problems that are being encountered are hematological problems. To restore the hematological parameter toward normal level by treatment with EECK clearly indicates that the extract having protective action on hemopoietic system also.

The lack of balance between the reactive oxygen metabolites and the antioxidant defense systems leads to "oxidative stress" which deregulates various cellular functions causing pathological conditions. Reactive oxygen species formed in cancer tissues result in lipid peroxidation and subsequent increase in MDA and other TBARS levels. MDA, the end product of lipid peroxidation, a biomarker of oxidative stress, was reported to be higher in cancer tissues than in the non-diseased organ [12]. The present study showed that there is an increased level of TBARS in the EAC-bearing liver tissues but after treatment with EECK inhibited hepatic lipid peroxidation as revealed by reduction of MDA levels toward normal levels (Fig. 1). This indicated the reduction in free radical generation by EECK in tumor-bearing mice. 
GSH, a potent inhibitor of neoplastic proliferation process, plays a crucial role as an endogenous antioxidant system. It was found particularly in high concentration in liver and is known to have a key function in the protective process [10]. The level of reduced GSH was decreased in cancer-bearing mice which may be due to its utilization by the excessive amount of free radicals generated in the disease state. Treatment with EECK was found to increase the GSH content in the liver and kidney as compared to the tumor control group (Fig. 1).

Superoxide dismutase (SOD), CAT, and GSH peroxides are involved in the clearance of superoxide and hydrogen peroxide $\left(\mathrm{H}_{2} \mathrm{O}_{2}\right)$. SOD catalyzes the diminution of superoxide into $\mathrm{H}_{2} \mathrm{O}_{2}$, which has to be eliminated by GSH peroxidase and/or catalase. Further, it has been reported that a decrease in SOD activity in EAC-bearing mice may be due to loss of $\mathrm{Mn}^{2+}$ containing SOD activity or due to neutralization of superoxide in EAC cells and the loss of mitochondria, leading to a decrease in total SOD activity in the liver [13]. The present study showed that there is a decreased level of SOD in the EAC-bearing tissues, but after treatment with EECK, it restored the SOD level toward normal (Fig. 1).

\section{CONCLUSION}

Cancer results from a series of molecular events that fundamentally alter the normal properties of cells. In cancer cells, the normal control systems that prevent cell overgrowth and the invasion of other tissues are disabled [14]. Current cancer chemotherapy can damage or kill the rapid dividing healthy cells and causes serious side effects such as neutropenia and anemia. In addition, the cost of chemotherapy drug is high. Natural compounds may reduce these problems. Currently, a few plant products are being used to treat cancer effectively [15-17].

The ethanolic extract of Cyperus kyllingia root possesses significant anticancer activity in vivo and increased the life span of tumorbearing mice. The phytochemical study confirmed the presence of compounds, namely glycosides, saponins, flavonoids, tannins, and phenolic compound, in ethanolic extract of $C$. kyllingia root which may possess these properties. The result of the present investigation is quite encouraging, and it explores the potent anticancer activity of ethanolic extract of $C$. kyllingia root probably because of its direct cytotoxic effect which is further potentiated by its antioxidant properties. Further, investigations are in progress in our laboratory to identify the active principles involved in this anticancer activity.

\section{ACKNOWLEDGMENTS}

We greatly acknowledge the Gupta College of Technological Sciences, Asansol, Department of Pharmaceutical Technology, Jadavpur University, Kolkata, West Bengal, India, Himalayan Pharmacy Institute, Majhitar, and Bengal College of Pharmaceutical Sciences and Research, Bidhannagar, for financial and technical support.

\section{AUTHORS' CONTRIBUTION}

The design of the research work was done by Dr. Pallab Kanti Haldar and Mr. Mainak Chakraborty. The experimental part of the work and writing of the manuscript was done by the corresponding author Mr. Amites Gangopadhyay. The correction and the revision of the manuscript were done by Dr. Nitai Chand Chaulya and Dr. Amitava Ghosh.

\section{CONFLICTS OF INTEREST STATEMENT}

We declare that we have no conflicts of interest.

\section{REFERENCES}

1. Shaikh R, Pund M, Dawane A, Lliyas S. Evaluation of anticancer, antioxidant, and possible anti-inflammatory properties of selected medicinal plants used in Indian traditional medication. J Tradit Complement Med 2014;4:253-7.

2. Haldar S, Karmakar I, Chakraborty M, Ahmad D, Haldar PK. Antitumor potential of Thevetia peruviana on ehrlich's ascites carcinoma-bearing mice. J Environ Pathol Toxicol Oncol 2015;34:105-13.

3. Nepal A, Chakraborty M, Karmakar I, Bala A, Haldar PK. Cytotoxic and antiproliferative activity of Hymenodictyon excelsum in ehrlich ascites carcinoma bearing mice: In vitro and in vivo studies. Int J Chem Pharm Anal 2016;3:1-7.

4. Khamsan S, Liawruangrath B, Liawruangrath S, Teerawutkulrag A, Pyne GS, Garson JM. Antimalarial, anticancer, antimicrobial activities and chemical constituents of essential oil from the aerial parts of Cyperus kyllingia endl. Rec Nat Prod 2011;5:324-7.

5. Komai K, Tang CS. Chemical constituents and inhibitory activities of essential oils from Cyperus brevifolius and Cyperus kyllingia. J Chem Eco 1989;15:2171-6.

6. Bala A, Kar B, Haldar PK, Mazumder UK, Bera S. Evaluation of anticancer activity of Cleome gynandra on ehrlich's ascites carcinoma treated mice. J Ethnopharmacol 2010;129:131-4.

7. Gangopadhyay A, Sinha S, Chaulya NC, Ghosh A. Phytochemical investigation and exploration of CNS depressant efficacy of ethanolic root extract of Cyperus kyllinga Endl. Indian J Exp Biol 2017;55:799-802.

8. OECD. Guidelines for the Testing of Chemicals/Section 4: Health Effects Test No. 425: Acute Oral Toxicity: Up-and-Down Procedure. Paris: Organisation for Economic Co-Operation and Development Publishing; 2008.

9. Chakraborty M, karmakar I, Haldar S, Nepal A, Haldar PK. Anticancer and antioxidant activity of ethanolic extract of Hippophae salicifolia in EAC induced Swiss albino mice. Int J Pharm Pharm Sci 2015;7:1-5.

10. Haldar PK, Kar B, Bala A, Bhattacharya S, Mazumder UK. Antitumor activity of Sansevieria roxburghiana rhizome against Ehrlich ascites carcinoma in mice. Pharm Biol 2010;48:1337-43.

11. Mondal A, Singha T, Maity TK, Pal D. Evaluation of antitumor and antioxidant activity of Melothria heterophylla (Lour) Cogn. Indian J Pharm Sci 2013;75:515-22

12. Roy S, Kumari D, Chakraborty M, Haldar PK. Anti-proliferative activity of Calamus rotang as a spotlight on ehrlich's ascites carcinoma treated peritoneal as well as solid tumor model. Int J Pharm Pharm Sci 2018;10:85-90.

13. Pal P, Chakraborty M, Karmakar I, Haldar S, Das A, Haldar PK. Evaluation of anticancer activity of ethanolic extract of Monstera deliciosa in EAC induced Swiss albino mice. Int J Toxicol Pharm Res 2015;7;165-70.

14. Prasad N, Ezzat S, Ismail L. Antioxidant and anticancer activities of high pressure-assisted extract of longan (Dimocarpus longan Lour) fruit pericarp. J Innov Food Sci Emerg Technol 2009;10:413-9.

15. Kumar RS, Rajkapoor B, Perumal P. In vitro and in vivo anticancer activity of Indigo feracassioides Rottl. Ex. DC. Asian Pac J Trop Med 2011;379-85.

16. Aishwarya V, Abdulla SS, Dheeba B, Renuka R. In vitro antioxidant and anticancer activity of Cardiospermum halicacabum l. Against eac cell line. Int J Pharm Pharm Sci 2014;6:263-68.

17. Melanathuru V, Rengarajan S, Thangavel N. Comparative study of antioxidant and anticancer activity of Alpinia calcarata and Alpinia galanga. Int J Pharm Pharm Sci 2017;9:186, 93. 